\title{
Corrigendum to "Selective Progesterone Receptor Modulators for the Medical Treatment of Uterine Fibroids with a Focus on Ulipristal Acetate"
}

\author{
Thomas Rabe $\mathbb{D}^{1},{ }^{1}$ Nicole Saenger, ${ }^{2}$ Andreas D. Ebert $\mathbb{D}^{3},{ }^{3}$ Thomas Roemer, \\ Hans-Rudolf Tinneberg, ${ }^{5}$ Rudy Leon De Wilde $\mathbb{D}^{6},{ }^{6}$ and Markus Wallwiener ${ }^{7}$ \\ ${ }^{1}$ Deutsche Gesellschaft für Gynäkologische Endokrinologie und Fortpflanzungsmedizin, Germany \\ ${ }^{2}$ Klinikum für Frauenheilkunde und Geburtshilfe, Frankfurt/M, Germany \\ ${ }^{3}$ Praxis für Frauengesundheit, Gynäkologie und Geburtshilfe, Berlin, Germany \\ ${ }^{4}$ Evangelisches Krankenhaus Weyertal gGmbH, Köln, Germany \\ ${ }^{5}$ Universitätsklinik Gießen und Marburg, Campus Gießen, Germany \\ ${ }^{6}$ Klinik für Frauenheilkunde, Geburtshilfe und Gynäkologische Onkologie; Universitätsklinik für Gynäkologie, \\ Pius-Hospital Oldenburg, Germany \\ ${ }^{7}$ Universitäts-Frauenklinik Heidelberg, Germany \\ Correspondence should be addressed to Thomas Rabe; thomas_rabe@yahoo.de
}

Received 16 October 2018; Accepted 18 October 2018; Published 28 November 2018

Copyright (c) 2018 Thomas Rabe et al. This is an open access article distributed under the Creative Commons Attribution License, which permits unrestricted use, distribution, and reproduction in any medium, provided the original work is properly cited.

In the article titled "Selective Progesterone Receptor Modulators for the Medical Treatment of Uterine Fibroids with a Focus on Ulipristal Acetate" [1], the affiliation of the third author was incorrect. The corrected affiliation is shown above. In addition, the Conflicts of Interest section should be updated as follows:

The authors have each previously received financial support from Gedeon Richter, who market ulipristal acetate as ESMYA ${ }^{\circledR}$. Thomas Rabe received fees for lectures, publications, and participation on the advisory board before retiring in 2016, Thomas Roemer received fees for lectures and consultancy work, Nicole Sänger has been a consultant for Gedeon Richter and has received travel expenses and lecture fees, Hans-Rudolf Tinneberg received fees for lectures, Andreas D. Ebert received financial support for lectures and the establishment of the Myom-Netwerk, Markus Wallwiener received a honorarium for a congress presentation, and Rudy Leon De Wilde was reimbursed for costs concerning a presentation on myoma surgery.

\section{References}

[1] T. Rabe, N. Saenger, A. D. Ebert et al., "Selective progesterone receptor modulators for the medical treatment of uterine fibroids with a focus on ulipristal acetate," BioMed Research International, vol. 2018, Article ID 1374821, 12 pages, 2018. 


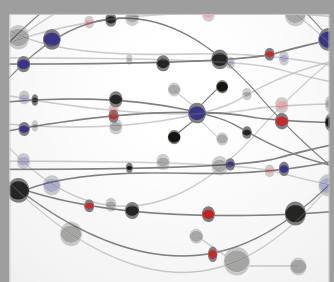

The Scientific World Journal
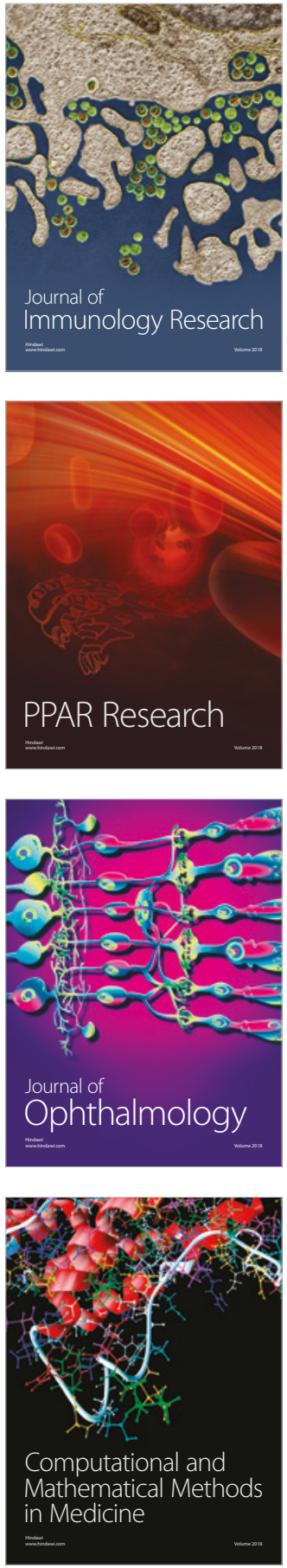

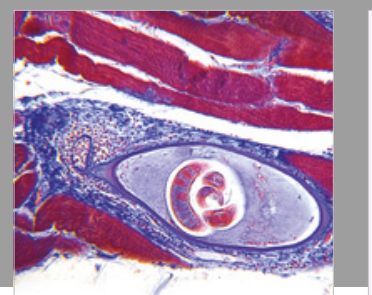

Gastroenterology Research and Practice

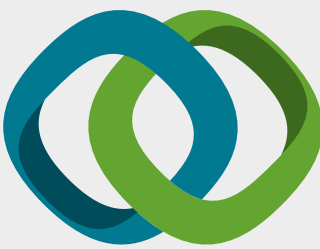

\section{Hindawi}

Submit your manuscripts at

www.hindawi.com
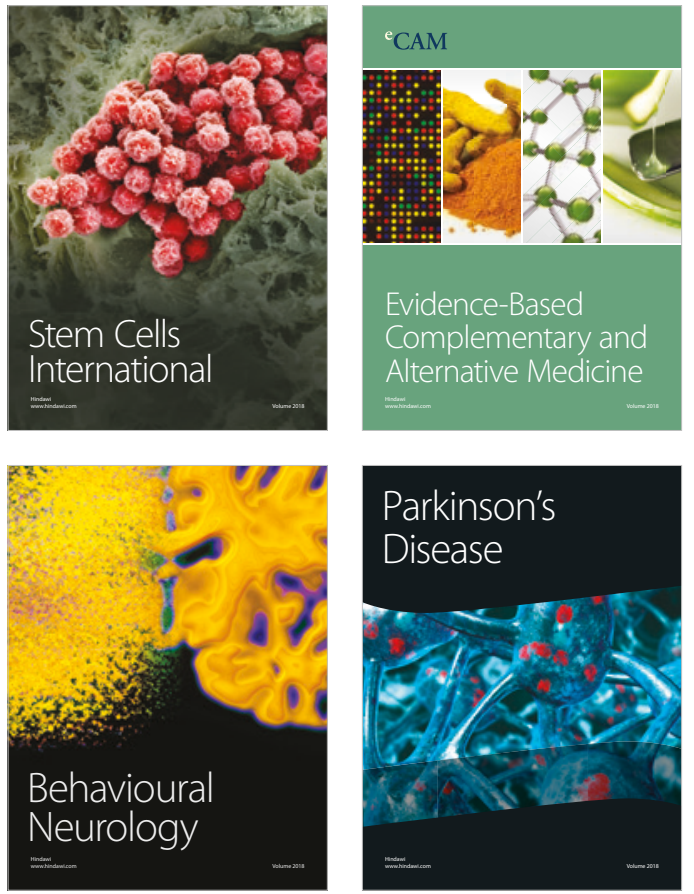

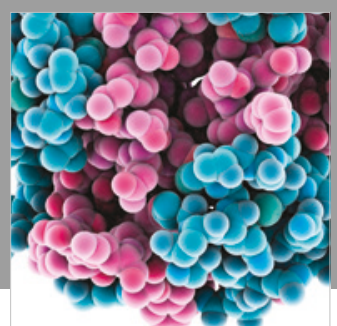

ournal of

Diabetes Research

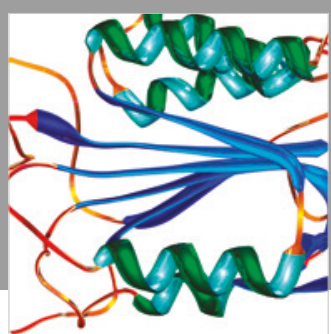

Disease Markers
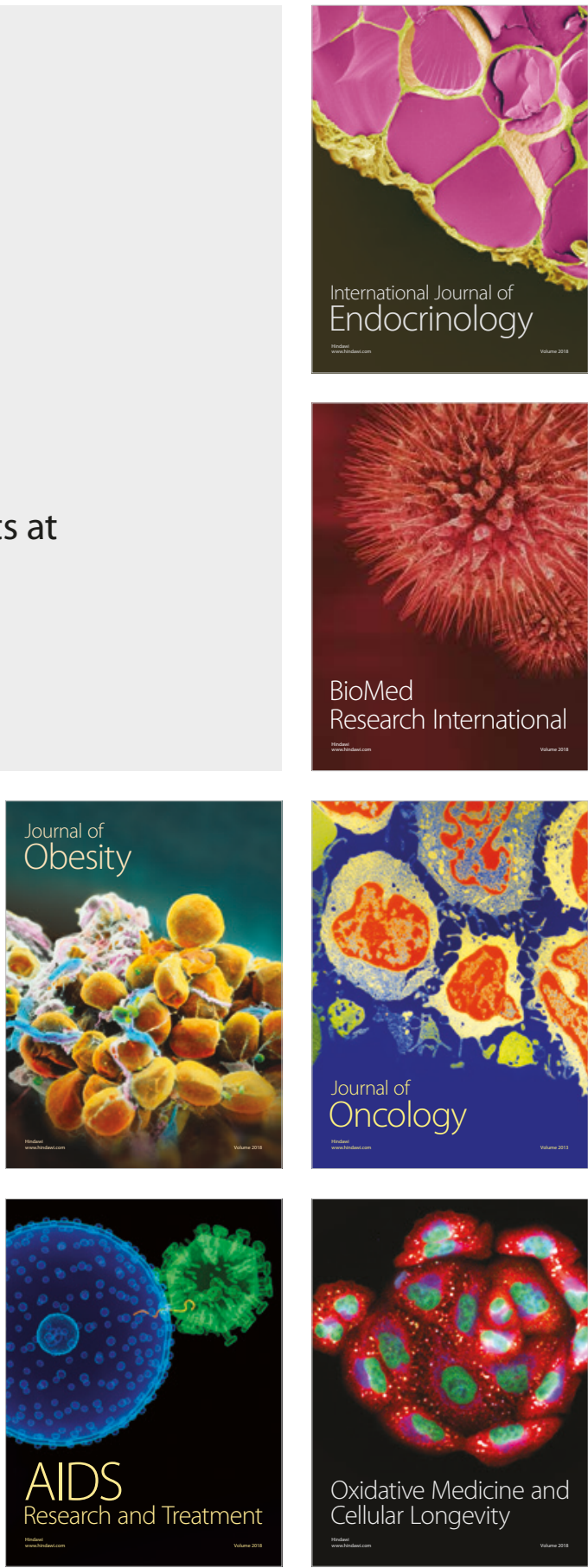